\title{
Plato, Aristotle \& the Dialectics of Poetry
}

\author{
Bikash Sharma \\ Assistant Professor (Department of English) \\ Sikkim Government College, Gyalshing, India \\ Email: bkas49@gmail.com
}

\begin{abstract}
The present paper attempts at estimating the legacy of two of the seminal philosophical minds, Plato and Aristotle. Their ideas have been so instrumental in shaping western critical literary tradition that any discussion on literary theory and criticism has to have them as a point of reference. Plato's negative conception of mimesis is juxtaposed with Aristotle's affirmative stand. The paper also examines the various philosophical and pragmatic charges labelled against poetry by Plato in his works such as Republic, Phaedrus and Ion. The paper concludes with a general overview of critical responses to Plato by succeeding men of letters.
\end{abstract}

Keywords: Plato, Aristotle, Literary theory, criticism, mimesis

\section{INTRODUCTION}

The process of poetic creation has since long been a matter of constant debate in the literary theoretical circle. Since classical antiquity, this idea has been subjected to frequent negotiations. Any diachronic investigation on literary theory is inevitably concerned with questions relating to the moral and social agency of art. The earliest discussions on the ontological essence and epistemological dimensions of art is inexorably linked to poetry. Where does poetry come from? What is its social and cultural validity? These questions are the common threads which bind literary thinkers from Plato to Aristotle, from Horace to Dryden or from Shelley to Eliot. In fact, the Platonic- Aristotelian debate about mimesis (Greek for imitation), on which much of modern literary theory rests, is more concerned with determining the ontological essence of art than anything else.

\section{PLATO, ARISTOTLE AND THE STATUS OF POETRY}

We know that Plato had an aversion for art, though he admired Homer, because he believed, that a work of art being imitative has a corrupting influence, it miseducates the ideal citizens of the ideal society. For the Athenian sage, the greatest human potential was the quest for truth and as humans one should strive for it. Much of Plato's negative conception of mimesis stems from his Theory of Forms. He believed in the existence of a parallel universe, different from the physical world we live in. He calls the ideal world the 'World of Being' as opposed to the 'World of Becoming', the corporeal world of change, decay and death. For Plato, everything in our physical world, from objects to ideas, is but a representation or mimesis of the unchanging originals, the forms of those objects or ideas which exist in the real world, the World of Being. When a poet writes a poem about time, for instance, he bases his poem on the concept of time that exists in the World of Becoming rather that the ideal form or concept of time that exists in the World of Being. Since poets write about objects and ideas from the physical world, which are themselves an imitation of their forms in the unchanging ideal world of being, hence, poetry is twice removed from the world of forms - twice removed from reality. This being-becoming dichotomy is at the very heart of Plato's dialectics.

Plato's negative conception of poetry is apparent in book X of his Republic. It is where he propounds his famous theory of forms which raises questions on the moral agency of poetry. His dialogues also raise few 
pertinent questions on the social function of poetry. In his Phaedrus Plato anticipates Freudian notion of the tripartite nature of the human psyche. He believed that human psyche is not a singular or monolithic entity, rather, it is divided into three parts, the rational side, the irrational and the mediating side. He consummates this idea by giving a beautiful and illustrative metaphorical parallel.

\section{MAIN PART}

Human mind, Plato says, is like a chariot driven by two winged horses, one sane and the other insane, steered and controlled by the charioteer. Poetry, being fanciful and counterfeited appeals to the irrational side of the human psyche, unlike mathematics, natural sciences and philosophy which are apprehended by means of our cerebral faculty, thereby making the readers emotionally vulnerable and weak. Further, in his Ion Plato tactfully concludes that poetry is a kind of madness or contagion. He presents a beautiful analogy of a magnet with series of iron rings attached one after another. Just as the magnetic current flows from the magnet into one ring leading to the other, the divine frenzy of poetry passes down from God to the poet to the rhapsode and then to the audience. Plato quotes, "For the poet is a light and winged and holy thing, and there is no invention in him until he has been inspired and is out of his senses, and the mind is no longer in him: when he has not attained to this state, he is powerless and is unable to utter his oracles." Further, he says, "...that the poets are only the interpreters of the Gods by whom they are severally possessed" In short, for Plato poetry is bad because it is a result of divine possession causing absolute delirium.

\section{ANALYSES}

Plato's ideas have been so pervasive and far ranging that a thinker aptly describes that all of western philosophy is but a series of footnotes to Plato. Such has been his influence as a man of great acumen. His ideas have greatly helped in shaping modern disciplines from literature to politics, psychology to law, philosophy to logic and so on. In the context of literary theory, Plato has to be seen as a beginning, the originary source or, to use a word oft repeated, the logos. Every form of literary theory, be it the pragmatic orientation of Aristotle or Longinus or the objective approach of Eliot or Brooks, is in one way or the other a response to Plato's notion of mimesis, social usefulness of poetry and the moral agency of the poet.

Aristotle's notion of mimesis differs significantly from that of Plato's. Poetry for Plato was bad for various metaphysical and psychological reasons discussed above. Aristotle vitalized and energized the poetic process as something positive and invigorating. He raised the status of poetry which had received a cogent blow from Plato's dialectics. The mimetic process, Aristotle claims, is a positive, natural and powerful tool. As children we learn through imitation. Even as grown-ups we share a propensity for aesthetic appreciation of art. In fact, it is the very mimetic process which enhances the aesthetic quality of an object or idea that may otherwise in reality be ugly or unpleasurable. Who likes war? Nobody does. But we do appreciate a painter's pictorial representation of war, for that matter even bloodshed. For Aristotle, the imitative process is what makes literature truer than history. While history is fact-based or incidental, literature is imaginative, philosophical and transcendental in nature. It defies temporal and spatial bounds. Shakespeare, for instance, 'is not for an age'. If history is characterized by incidental fidelity and particularity, literature is rendered unique by its universality. This positive conception of the mimetic process has been Aristotle's eternal legacy to the field of literary studies. 
Aristotle also negates the Platonic notion that art, particularly poetry appeals to the weaker, inferior side of human psyche thereby making them emotionally vulnerable. In chapter VI of Poetics he not only defines tragedy (by which he meant poetic drama of Periclean Athens) from an ontological perspective but also discusses the impact it has on the ideal audience. Tragedy, for Aristotle, "is an imitation of an action that is serious, complete and of certain magnitude; in language embellished with each kind of artistic ornaments; the various kinds being found in the separate parts of the play; in the form of action, not of narrative; with incidents arousing feelings of pity and fear wherewith to accomplish the catharsis of such emotions." This compendious definition provides a fitting defense against Plato's charges of poetry being socially harmful and contagious. Tragedy arouses in the audience feelings of pity and fear in a controlled setting leading to the purgation of such emotions. Aristotle believed that human beings are, by virtue of being human, emotional beings. The emotions however, are never stable. Tragedy helps us rinse away our excess base emotions leaving us emotionally and mentally poised. This claim that literature serves useful social function is later echoed in Sir Philip Sidney's famous Defense of Poesy (1595). Sidney defines tragedy as "high and excellent" form, "that openeth the greatest wounds, and showeth forth the ulcers that are covered with tissue. That maketh kings fear to be tyrants. That, with stirring the effects of admiration and commiseration, teacheth the uncertainty of this world, and upon how weak foundations gilded roofs are builded." Sidney's admiration and commiseration are almost equivalent to Aristotle's pity and fear however he lays more importance on the didactic function of literature. Nonetheless, Sidney too like Aristotle validates the social usefulness of literature.

\section{DISCUSSIONS}

The debate about the social utility of poetry and moral agency of poets does not end with Plato and Aristotle. In fact, literary theory up to the present age is to a large extent an attempt at assessing and addressing those very questions. The Roman poet critic Horace talks affirmatively about the social relevance of poetry in his Ars Poetica. He says that a good work of art should serve dual purpose of instructing and pleasing - Dulce et utile to use Horace's phrase; the Greek thinker Longinus talks at length about the impact that a sublime poem has on an ideal cultivated audience in his treatise On Sublimity. The renaissance man, Sir Philip Sidney in his Defense of Poesy not only puts forth a formal defense against Plato's allegation that all imitative art is bad, he also had to mount a defense against contemporary reservations and doubts on the sanctity of literary art. Stephen Gosson's in The School of Abuse (1579) condemns poetry for being 'mother of lies' and 'the nurse of abuse'. Sidney responds by claiming that literature is highest form of philosophy. Poetry, by uniting the universality of philosophy with particularity of history makes it superior than the both.

\section{CONCLUSIONS}

Literature progresses and evolves along such conflicting standpoints, so has been the story of poetry. In every epoch poetry has been and will be seen with a sense of suspicion. As the world becomes more technological and scientific the doubts will certainly intensify. What place do poets occupy in this modernday complex world order? Is poetry becoming redundant and useless? Such questions loom large and do make plausible claims too. However, poetry continues to be written and appreciated, and so does the debate. The modern poet W.H. Auden once remarked, "Nothing I wrote saved a single Jew from being gassed ... it's 
perfectly all right to be an engagé writer as long as you don't think you're changing things. Art is our chief means of breaking bread with the dead . . . but the social and political history of Europe would be exactly the same if Dante and Shakespeare and Mozart had never lived." As discussed earlier, the process of poetic creation has been a much-contested issue from Plato to Eliot and beyond. However, poetry continues to be written and consumed and in that process criticism thrives. Poetry may not change the historical or political trajectory of the world, as Auden says, but the study of it certainly charters the marvelous imaginative course of mankind..

\section{REFERENCES}

[1] Agbaje, I, (2012). Towards Achievement of Sustainable Development through Technical and Vocational Education and Training (TVET): A case of Middle Level Colleges- Kenya. Journal of Emerging Trends in Educational Research and Policy Studies, 3(5), 686 - 690

[2] Chiapaka, I. J. (2012). "Towards curbing youth restiveness”, in Nigerian Tide, (p.2). 20th August

[3] Elegbeleye, O. S. (2005). Recreational facilities in schools: A panacea for youths' restiveness. Journal of Human Ecology 18 (2): 9398.

[4] Federal Government of Nigeria, (2001). National Youth Policy; http://www.thepresidency.gov.za/docs/policy/nationalyouthpolicy.pdf.

[5] John, I. (2005). Diversity and inclusion: Towards a curriculum for humanbeings. Teachers College Record, 95(2) 211-221.

[6] Kumar, L (2008). Sustainable Agriculture Production: Implications for International Agricultural Research. FAO Research and technology paper 4. Rome, Italy

[7] Misham S. V. (2007). Moral decadence among the student. Abuja: Ventures Books Ltd.

[8] Njoku N. C. (2015). Repositioning Nigeria Youths through the teaching of moral institution in the 21st century. British Journal of Education, 3(7) 9-17.

[9] Odeh, J.C. (2015). Moral decadence among catholic youths in Abakaliki diocese. Unpublished Thesis of Ebonyi State University, Abakaliki.

[10] Olusanya, J. O. (2013). Towards national security and transformation: Vocational and technical education option. Keynote address presented at the 11th National Conference on Vocational and Technical Education, Abeokuta, 2nd July.

[11] Omede, B (2012) Revised Recommendation Concerning Technical and Vocational Education. In Normative Instruments concerning technical and vocational education. Online: http://www.unevoc.unesco.org/go.php?q=UNEVOC+publicatins\&lang=en\&akt=i\&st= $\& q s=70 \&$ unevoc $=$ i. Retrieved 20/02/2012 UNESCO (2005). Learning for Work, C

[12] Ozohu-Suleiman, A. (2006) "The Nigerian youth in contemporary political development: Relevance, challenges and role expectation", in the constitution: A journal of constitutional development (p. 97-111) vol. 6(4).

[13] Rogas P. S. (2003). Moral Development and Moral education. London: Allen \& Union.

[14] Saheed, I.T. (2013). Moral decadence, causes, effects and solution. Journal of Education and Management Sciences, 2(4), 122-144.

[15] Irgashevich, D. A. (2020). Development of national network (tas-ix). ACADEMICIA: An International 
Multidisciplinary Research Journal, 10(5), 144-151. Article http://dx.doi.org/10.5958/2249-7137.2020.00254.2 